\title{
Knowledge and behavior of women on cervical cancer in the northern region of Cameroon
}

\author{
Georges $\mathrm{K}^{1}$, Armel Herve $\mathrm{NK}^{1 *}$, Simo Richard $\mathrm{T}^{1}$, Jeremie $\mathrm{MA}^{1}$ and Charlette $\mathrm{N}^{2}$ \\ ${ }^{1}$ Deparment of Biomedical Sciences, Faculty of Sciences, University of Ngaoundere, Ngaoundere, Cameroun. \\ ${ }^{2}$ Anato-Cytopathology Laboratory, University Hospital Center of Yaounde, Yaounde, Cameroun
}

\begin{abstract}
Cervical cancer is the second common cancer among women worldwide. The aim of this study was to evaluate the knowledge and behaviors of women on cervical cancer in the northern region of Cameroun. 307 women were recruited and include in statistical analysis. Age was varying between 20 to 62 years. After obtaining informed consent, a questionnaire was administrated to each woman on sociodemographic characteristics, gynecological and obstetric history and knowledge on cervical cancer. This study reported that women in the northern region of Cameroon have weak knowledge about cause (10,74\%), means of preventing methods $(14,65 \%)$ of cervical cancer and just $2,93 \%$ were screening before. $27.36 \%$ have never heard about cervical cancer. This situation shown that there is a real need for public aware about cervical cancer in the northern region of Cameroon to fight against this cancer.
\end{abstract}

\section{Introduction}

Cancer is a pathology characterized by an anarchic and uncontrolled proliferation of cells. Cancer can reach all organs [1,2]. Cervical and breast cancer are the most frequent cancers in women in the world. Cervical cancer is in terms of frequency, the second cancer affecting women. It represents 20 to $30 \%$ of all cancers in women [3]. In 2005, nearly 500,000 new cases and 260,000 deaths were recorded [4]. More than 528000 new cases and approximately 275000 deaths in 2012. The $80 \%$ of these deaths occur in developing countries, countries in which this cancer is the leading cause of cancer deaths in the female population [5].

In Cameroon, work in semi-urban areas has found $57 \%$ of cervical cancers among gynecological cancers [6]. This cancer in most women is diagnosed at a later stage [7]. This is due to the long delay between the beginning of symptoms and the treatment and the lack of a national strategy for screening and vaccination. Indeed, surveys have shown that the knowledge, attitudes and practices of Cameroonian women and health workers on HPV (Human Papilloma Virus) and cervical cancer are low $[8,9]$.

Cervical cancer is a prevenTableand curable disease, but provided it is detected early and treated [10]. In developed countries, early detection has significantly reduced the incidence of cervical cancer. This action should be included in a well-defined and adapted control program $[5,11]$. The success of a screening program depends to a large extent on the target population, their level of knowledge about the disease and the level of awareness [12]. Cameroon have not a cervical cancer control program. Cervical cancer control activities are limited to sporadic screenings by the National Cancer Control Committee. The level of awareness of the population on cervical cancer is thus limited. A study in Nigeria on women referred for cervical cytology showed that only $39.5 \%$ had heard of cervical cancer and only $15.1 \%$ had screening before [13].

A study in the Maldives in South Asia also showed a poor knowledge of the female population on cervical cancer, $37.9 \%$ had expected to talk about cervical cancer [14]. Knowledge of the sexually transmitted origin of cervical cancer by women in Qatar is 24.8\% [15]. The population of Northern Cameroon is generally poor and women are less educated.

Awareness is the first weapon used in disease control strategies. A good awareness is translated in the population by a level of knowledge of the etiology, the risk factors, the means of prevention and accepTabletreatment regarding the disease.

The aim of this study was to evaluate women's knowledge on cervical cancer in the Northern region of Cameroon to undertake an appropriate and effective method of awareness and fight against cervical cancer.

\section{Materials and methods}

This is a cross-sectional descriptive study conducted in the Northern region of Cameroon from May 02 to August 13, 2016 in the following hospitals: Regional Hospital of Garoua, District Hospital of Guider and Esperance Hospital of Djamboutou (Garoua). 307 were included in the statistical analyzes. Inclusion criteria were all women age 20 to 65 years old who were consulted in hospitals. After obtaining informed consent, a questionnaire was administered to each woman on the sociodemographic characteristics, gynecological and obstetric history and knowledge on cervical cancer.

Correspondence to: Armel Herve Nwabo Kamdje, Ph.D, Department of Biomedical Sciences, University of Ngaoundere, Cameroon, Tel. +23777463063/+23790190421;E-mail: kamdjewa@yahoo.fr / ah.nwabo@univ-ndere.cm

Key words: knowledge, behaviors, cervical cancer

Received: April 10, 2017; Accepted: May 22, 2017; Published: May 25, 2017 


\section{Results}

\section{Age}

The women recruited in this study were between 20 and 62 years old. The mean age was $34.72 \pm 8.82$ years.

\section{Marital status}

The following Tableshows the distribution of women by marital status

\section{Type of marriage}

The monogamous marriage was the most represented with 192 cases or $62.54 \%$. The polygamous marriage was represented at $31.59 \%$ or 97 cases and the singles constituted the rest (Table 1).

\section{The level of schooling}

The Table 2 below shows the distribution of women according to their level of schooling.

In Table 2, we find that women at the primary level were the most represented at $28.01 \%$. Not schooling women also represented a significant proportion of the sample at $27.68 \%$.

\section{Socio-Professional Category}

Table 3 presents the distribution of women recruited in our study according to the socio-professional category.

Housewives were the most represented in this study with $28.01 \%$ followed by health care workers (11.72\%).

Table 1. Distribution of women according marital status.

\begin{tabular}{|l|c|c|}
\hline Marital status & Effective & Percentage (\%) \\
\hline Married & 236 & 76,87 \\
\hline Divorced & 29 & 9,44 \\
\hline Widow & 24 & 7,81 \\
\hline Single & 18 & 5,86 \\
\hline Total & 307 & 100 \\
\hline
\end{tabular}

Table 2. Distribution of women according level of schooling.

\begin{tabular}{|l|c|c|}
\hline & Effective & Percentage (\%) \\
\hline Not schooling & 85 & 27,68 \\
\hline Primary level & 86 & 28,01 \\
\hline Secondary first cycle & 65 & 21,17 \\
\hline Secondary second cycle & 51 & 16,61 \\
\hline University level & 20 & 6,51 \\
\hline Total & 307 & 100 \\
\hline
\end{tabular}

Table 3. Distribution of women according to socio-professional category.

\begin{tabular}{|l|c|c|}
\hline & Effective & Percentage (\%) \\
\hline Housewife & 176 & 57,32 \\
\hline Health personnel & 36 & 11,72 \\
\hline Trader & 23 & 7,81 \\
\hline Farmer & 20 & 6,51 \\
\hline Teacher & 19 & 6,18 \\
\hline Secretary's office & 12 & 3,90 \\
\hline Other & 21 & 6,84 \\
\hline Total & 307 & 100 \\
\hline
\end{tabular}

\section{Age of First sex intercourse}

The age at first intercourse of the women who participated in the study was between 13 and 30 years. The mean age at first intercourse was 17.52 years with a standard deviation of 2.80 (Table 4 ).

\section{Parity}

The number of births is among 0 to 14 . The mean was 3.89 with a standard deviation of 2.91 . The following Table 5 present the distribution of women according to the number of birth.

Knowledge about cause and means of preventing cervical cancer.

\section{Discussion}

The mean age of $34.72 \pm 8.82$ years was observed in our study with extremes of 20 and 62 years. The 20 -year-old extreme could be considered early for the evaluation of knowledge and practices regarding cervical cancer although the natural history of this pathology tells us that it appears very late with an incidence rate that increases up to 40 years and then decreases [16]. Scientific journals also require that screening be carried out from the age of 25 years. Bernard, in his study in French, chose as his minimum age of 25 years [17]. However, studies such as Nkegoum in Cameroon have shown a high prevalence of precancerous lesions in women under 25 years old [18].

The level of schooling is a protective factor for the contraction of STD, particularly HPV. However, in our study the women recruited were mainly at primary level $(28.01 \%)$ and women not attending school (27.68\%). This situation confirms the low level of schooling of women in the northern region of Cameroon and can be a determent risk factor, unlike the study conducted by Haliloglu et al., reported that $54.71 \%$ of women were secondary and Tchounzou et al. in 2015 Women were predominantly university-educated [19].

In our study, $57.82 \%$ were housewives; $11.72 \%$ were health workers and the rest were traders, farmers, and others. This distribution reflects

Table 4. Distribution of women by age of first sex intercourse.

\begin{tabular}{|l|c|c|}
\hline Age of first sex intercourse & effective & Percentage (\%) \\
\hline$[13-18]$ & 212 & 69,06 \\
\hline$[19-30]$ & 95 & 30,94 \\
\hline Total & 307 & 100 \\
\hline
\end{tabular}

Table 5. Distribution of women according to the number of birth.

\begin{tabular}{|l|c|c|}
\hline Parity & Effective & Percentage \\
\hline 0 & 36 & 11,73 \\
\hline$[1-4]$ & 115 & 37,73 \\
\hline$[5-15]$ & 156 & 50,81 \\
\hline Total & 307 & 100 \\
\hline
\end{tabular}

Table 6. Knowledge of women on cervical cancer.

\begin{tabular}{|l|c|c|}
\hline & Effective & Percentage \\
\hline Women who have heard about cervical cancer & 223 & $72.26 \%$ \\
\hline Women never heard about cervical cancer & 84 & $27.36 \%$ \\
\hline $\begin{array}{l}\text { Women who are knowing HPV as a cause of cervical } \\
\text { cancer }\end{array}$ & 33 & $10.74 \%$ \\
\hline $\begin{array}{l}\text { Women who are not knowing HPV as cause of cervical } \\
\text { cancer }\end{array}$ & 274 & $89.25 \%$ \\
\hline $\begin{array}{l}\text { Women who knowing regular screening as a mean of } \\
\text { prevention }\end{array}$ & 45 & 14.65 \\
\hline $\begin{array}{l}\text { Women screening before on cervical cancer } \\
\begin{array}{l}\text { Women who are never heard about cervical cancer } \\
\text { screening campaign }\end{array}\end{array}$ & 294 & 2.93 \\
\hline
\end{tabular}


the low socio-economic status of women in the northern region of Cameroon and can be a risk factor.

The mean age of first sexual intercourse was $17.52 \pm 2.80$ years with extremes of 13 and 30 years. Most women in our study (69.06\%) had their first sexual intercourse between 13 and 18 years. Early intercourse can be justifying by socio-cultural factors such as the early marriage of the girl in the region.

The mean parity of our study population was $3.89 \pm 2.91 ; 50.81 \%$ of women have parity between 1 and 4 and $37.46 \%$ have parity of 5 or more. Many studies have identified parity as an important risk factor of cervical cancer [20]. This parity appears to be high especially as women in our study population were relatively young and in childbearing age.

Cervical cancer despite its ravages in the world is still poorly known by many people. This is also true in our study population, where $27.36 \%$ have never heard about cervical cancer. This may be obvious given their low level of schooling. However, 223 women or $72.26 \%$ have already heard of cervical cancer. This seems to be the common problem found in other parts of the country such as Maroua, Buea and in other countries such as Gabon, Thailand [6,19,21,22]

Participants were unaware of HPV and its relationship with cervical cancer. Only 10.74 of our study population identified HPV as a major risk factor of cervical cancer. This is like the results found in Songea's rural area by James in 2011 [23] where just 10 women mentioned the human papilloma virus as the leading cause of cervical cancer. This reflects the level of knowledge of these women that makes it impossible to prevent infection by vaccination because the relation between HPV and cervical cancer is misunderstood.

Many women are unaware of methods of preventing cervical cancer. $85.35 \%$ were probably unaware, this because the lack of adequate information. Regular screening was mentioned by $14.65 \%$ of our population as a preventing method.

In this study, just 09 women or $2.93 \%$ were screening before. This is a problem in African countries where women have not used screening tests. This situation is found too in Ethiopia, where similar studies show that $6.5 \%$ have used a screening test [24]. Women in developing countries, particularly those in sub-Saharan Africa, do not routinely seek screening for precancerous lesions. The direct consequence of this reality is therefore an increase in the prevalence of precancerous and cancerous lesions contrary to that observed in developed countries [16]. The most common reasons for non-screening were ignorance at $95.76 \%$.

\section{Conclusion}

In this study, we noted that women living in the Northern Cameroon region have weak knowledge about the cause, means of preventing cervical cancer. This shows us that there is a real need for public awareness of this cancer. This awareness may be adapted with the local language in the northern region considering to the high rate of women who are not schooling. Although there is no pathologist in the northern region, informed women can be screened when traveling to large metropolises such as Douala and Yaounde where there are pathologists. They may also be more readily adherent to screening campaigns organized by the National Cancer Control Committee, although these screening campaigns remain sporadic.

\section{Authorship contribution}

All authors contributed to the design, preparation, editing, and final review of the manuscript.

\section{Acknowledgments}

Authors thank the collaborators of their respective institutions for the comments on the manuscript.

\section{References}

1. Mareel M, Leroy A (2003) Clinical, cellular, and molecular aspects of cancer invasion. Physiological Review 83: P337-76. [Crossref]

2. Hanahan D, Weinberg RA (2011) Hallmarks of cancer: the next generation. Cell 144 P646-674. [Crossref]

3. Pierre A (2013) Cancers in developing countries. Tropical medicine. P 01.

4. Yeni P (2010) Management of people infected with HIV. Recommendation of the expert group. The French documentation. Paris.

5. Cervical Cancer Action (2010) Progress towards cervical cancer prevention: A review of the CCA. P 6

6. Tebeu PM, P Petignat, P Mhawech-Fauceglia (2009) Gynecological malignancies in Maroua, Cameroon. International Journal of Gynecology \& Obstetrics 104: 148-149. [Crossref]

7. Sando Z, Tsuala Fouogue J, Ymele Fouelifack F, Fouedjio JH, Mboudou ET, et al (2014) Profile of gynecological and breast cancers in Yaoundé-Cameroon. Pan African Medical Journal 17.

8. Wamai RG, Ayissi CA, Oduwo GO, Perlman S, Welty E, et al. (2013) Awareness, knowledge and beliefs about HPV, cervical cancer and HPV vaccines among nurses in Cameroon: An exploratory study. International Journal of Nursing Studies 50: 13991406. [Crossref]

9. Tebeu PM, Major AL, Rapiti E, Petignat P, Bouchardy C (2008) The attitude and knowledge of cervical cancer by Cameroonian women; Maroua, the capital of the Far North Province of Cameroon. International Journal of Gynecological Cancer 18: 761 765. [Crossref]

10. WHO (2010) Cervical cancer in the African Region of WHO: current situation and prospects. Regional Committee for Africa 2010.

11. ACCP (2006) Planning and implementation of programs for the prevention and control of cervical cancer. Handbook for organizers.

12. Hulstaert F, Arbyn M, Huybrechts M, Vinck I, Puddu M, et al. (2006) Cervical cancer screening and HPV. KCE reports. $38 \mathrm{~B}$ p 64.

13. Akinlaja OA, Anorlu RI (2014) Knowledge of servical sancer, swareness and sttitude to screening among Patients at a Cytology Clinic. Austin J Obstet Gynecol 1: 4.

14. UNFPA (2013) Study of KAP of Women of Reproductive Health in Prevention and Early Detection of Cervical Cancer in Maldives. p. 15

15. FM Al-Meer, T Aseel, J Al-Khalaf, MG Al-Kuwari and MFS Ismail (2009) Knowledge, attitude and practices regarding cervical cancer and screening among women visiting primary health care in Qatar. [Crossref]

16. Duport N (2008) Epidemiological data on cervical cancer. States of knowledge. INVS

17. Bernard E (2012) Cervical cancer screening: women's knowledge and participation. Public Health (Vandoeuvre-les-Nancy, France) 25: 255-262.

18. Nkegoum, B, Belly Prisco E, Mbakop A, Gwet Bell E (2001) Precancerous lesions of the uterine cervix in cameroonian women. cytological and epidemiological aspects of 946 cases. Obstetric Gynecology \& Fertility 29: 15-20. [Crossref]

19. Ekane GEH (2015) Pap Smear Screening, the Way Forward for Prevention of Cervica Cancer? A Community Based Study in the Buea Health District, Cameroon. Open Journal of Obstetrics and Gynecology: 226.

20. Muñoz N, Bosetti C, Franceschi S (2002) Role of parity and human papillomavirus in cervical cancer: the IARC multicentric case-control study. The Lancet 359: 1093-1101. [Crossref]

21. Assoumou SZ, Mabika Mabika B, Ndjoyi Mbiguino A, Mouallif M, Khattabi A, et al. (2015) Awareness and knowledge regarding cervical cancer, Pap smear screening and human papillomavirus infection in Gabonese women. BMC Women's Health 15: 1.

22. Kietpeerakool C, Phianmongkhol Y, Jitvatcharanun K, Siriratwatakul U, Srisomboon J (2009) Knowledge, awareness, and attitudes of female sex workers to HPV infection, cervical cancer, and cervical smears in Thailand. International Journal of Gynecology \& Obstetrics 107: 216-219. [Crossref] 
23. John J (2011) The knowledge, attitude, practice and perceived barriers towards screening for premalignant cervical lesions among women aged 18years and above, in Songea urban, Ruvuma. Muhimbili University of Health and Allied Sciences.
24. Arulogun OS, Maxwell OO (2012) Perception and utilization of cervical cancer screening in university nurses, University College Hospital, Ibadan, Nigeria. Pan African Medical Journal 11. [Crossref]

Copyright: (C2017 Georges K. This is an open-access article distributed under the terms of the Creative Commons Attribution License, which permits unrestricted use, distribution, and reproduction in any medium, provided the original author and source are credited. 